\title{
BAGAIMANAKAH PERAN SERIKAT PEKERJA DALAM PENENTUAN UPAH SETELAH BERLAKUNYA PERATURAN PEMERINTAH NO. 78 TAHUN 2015 TENTANG PENGUPAHAN
}

\author{
Wawan \\ (Mahasiswa Program S1 Fakultas Hukum Universitas Tarumanagara) \\ (Email: wawanwon01@gmail.com)
}

\section{Andari Yurikosari}

(Corresponding Author)

(Dosen Hukum Ketenagakerjaan Fakultas Hukum Universitas Trisakti dan Fakultas Hukum Universitas Tarumanagara, Meraih Sarjana Hukum dari Fakultas Hukum Universitas Indonesia, Magister Hukum dari Fakultas Hukum Indonesia, Doktor Hukum dari Fakultas Hukum

Universitas Indonesia)

(Email: andari.yurikosari@gmail.com)

\begin{abstract}
Law no. 13 of 2003 on Manpower clearly regulates the determination of district minimum wage set by the Governor by taking into account the recommendations of the Wage Council, the Wage Council conducts a market survey to establish the standard of living needs of a person. The Manpower Act states that in the process of establishing a minimum wage the need for negotiations between the wage council, trade unions and employers' organizations. While the Governor looks for the middle line to set the minimum wage. After the issuance of Government Regulation no. 78 Year 2015 on Wages, minimum wage determination is no longer through negotiation, but through minimum wage calculation formula that is with the minimum wage of the current year, inflation and gross domestic income. The author intends to find out about the role of unions after the issuance of Government Regulation no. 78 of 2015 on remuneration, and determination of minimum wage. The author examines this issue using nomative research methods supported by expert interview data. The author analyzes that after the issuance of the Government Regulation on Remuneration of unions has ceased to function in the protection of workers' welfare.

Keywords: Role of Trade Unions, Wage Scale Structure, Collective Labor Agreement, wage determination.
\end{abstract}




\section{I.PENDAHULUAN}

\section{A. Latar Belakang}

Buruh merupakan suatu istilah yang sering dipakai saat ini, buruh oleh pengusaha sering di anggap seperti sapi perah, bahkan ada juga yang mengganggap buruh sebagai budak. Ada anggapan bahwa buruh adalah pekerja kelas bawah, orang yang melakukan pekerjaan kasar, membosankan, tidak memerlukan keahlian dan keterampilan tinggi, tempat kerjanya kotor, dan seterusnya ${ }^{1}$ Buruh sangat identik dengan buruh perindustrian dengan gaji atau pengupahan yang sangat rendah, bahkan sampai saat ini masih jauh dari kata kesejahteraan. Karena itulah orang yang bekerja lebih suka di panggil dengan pekerja, karena pekerja mempunyai konotasi status yang lebih tinggi, sebagai orang yang bekerja di tempat yang lebih nyaman, dan menerima gaji yang baik. ${ }^{2}$ Dalam prakteknya ternyata baik buruh maupun pekerja (arbeider) adalah sama-sama orang yang melakukan pekerjaan untuk orang lain (majikan/owner, dengan menerima upah dan kondisi yang sama. Banyak pekerja tidak sadar jika telah ditindas, yang menjadi faktor penyebab penindasan pekerja karena pekerja tidak mempunyai kekuatan untuk menyampaikan kelemahan yang dialami oleh mereka, dan yang menjadi penghalang paling besar adalah faktor ekonomi.

Diperlukannya ketentuan Perundang-Undangan untuk melindungi pekerja yang merasa dirugikan atas perbuatan yang dilakukan oleh pengusaha. Perlindungan hukum terhadap pekerja sendiri dalam prakteknya masih sangat minim, hal ini terbukti lewat masih banyaknya tindakan sewenang-wenang dari pengusaha terhadap pekerja. Dari sekian banyak permasalahan yang dialami pekerja terdapat permasalahan yang dapat dikatakan permasalahan yang cukup pokok, yaitu permasalahan pengupahan. ${ }^{3}$

Upah merupakan aspek yang paling sensitif di dalam hubungan kerja. Baik pekerja memiliki pandangan yang berbeda terhadap upah. Pekerja melihat upah

\footnotetext{
${ }^{1}$ Sehat Damanik, Hukum Acara Perburuhan. Cetakan ke-IV, (Mei, 2014), hal. 1.

${ }^{2}$ Ibid, hal. 1.

${ }^{3}$ Anonim. "Tujuh Masalah Ketenagakerjaan Di 2014 Ini Layak Diwaspadai", https://hukumonline.com, 07 Januari 2015.
} 
sebagai sumber penghasilan guna memenuhi kebutuhan hidup pekerja dan keluarganya, sedangkan bagi pengusaha upah merupakan bagian dari komponen biaya produksi.

Terbitnya Peraturan Pemerintah No. 78 Tahun 2015 tentang Pengupahan ini menuai pro dan kontra.Hal ini dikarenakan penetapan upah minimum berdasarkan Peraturan Pemerintah No. 78 Tahun 2015 tentang Pengupahan adalah dengan menggunakan formula perhitungan upah minimum. Formula upah minimum diatur di dalam Pasal 44 Ayat 2 Peraturan Pemerintah No. 78 Tahun 2015 tentang Pengupahan yang menyatakan bahwa formula perhitungan upah minimum sebagaimana dimaksud pada Ayat (1) sebagai berikut: $\mathrm{UMn}=\mathrm{UMt}+\{\mathrm{UMt} \mathrm{x}$ (Inflasit $+\% \Delta \mathrm{PDBt})\} .{ }^{4}$ Pekerja mengganggap formula perhitungan upah minimum yang hanya berdasarkan inflasi dan pertumbuhan ekonomi ini tidak berpihak pada pekerja. Sedangkan pemerintah mengganggap dengan formula perhitungan upah minimum maka akan terdapat kejelasan dan kepastian bagi perusahaan, karena pengusaha dapat memprediksi keuangan yang akan dikeluarkan oleh perusahaan untuk upah pekerja/buruh. ${ }^{5}$

Menurut Sekjen OPSI Timboel Siregar, pengaturan mengenai tata cara pemberian upah berdasarkan struktur skala upah sudah baik untuk membantu pekerja membuktikan upah yang diterimanya. Akan tetapi ia mengkritik keras sebagian ketentuan yang diatur dalam Peraturan Pemerintah No. 78 Tahun 2015 tentang Pengupahan, diantaranya mekanisme penetapan kenaikan upah minimum yang dipatok menggunakan formula yang ditentukan lewat tiga variabel yaitu upah minimum tahun berjalan, inflasi dan Pendapatan Domestik Bruto (PDB) nasional, sedangkan variabel Kebutuhan Hidup Layak (KHL) tidak digunakan. ${ }^{6}$

Perlindungan Negara terhadap pengupahan merupakan isu yang paling panas sejak dulu. Tahun ini, penentuan Upah Minimum Provinsi (UMP) adalah medan yang paling nyata bagi para pekerja atau buruh, sebagai contoh: Kenaikan upah

\footnotetext{
${ }^{4}$ Indonesia, Peraturan Pemerintah No. 78 Tahun 2015 tentang Pengupahan. Pasal 44 ayat 2. ${ }^{5}$ Anonim. "Inilah Hasil Kajian LIPI Tentang Penyusunan Peraturan Pemerintah Pengupahan", https://hukumonline.com, 03 November 2015.

${ }^{6}$ Andari Yurikosari, Fungsi Serikat Pekerja Dalam Pasca Peraturan Pemerintah Nomor 78 Tahun 2015 tentang Pengupahan dalam pengupahan upah minimum. hal. 1.
} 
buruh di DKI Jakarta Tahun 2018, harapan buruh mengeluarkan angka tuntutan sebesar Rp. 3.917.318 atau naik sebesar 13,9\% berdasarkan Komponen Hidup Layak (KHL) hasil survei Dewan Pengupahan Buruh Provinsi DKI Jakarta. ${ }^{7}$ Menteri Ketenagakerjaan (Menaker), Hanif Dhakiri, menetapkan Upah Minimum Provinsi (UMP) DKI Jakarta yaitu Rp. 3.648.035. ${ }^{8}$ Penghasilan yang layak merupakan jumlah penerimaan atau pendapatan Pekerja/Buruh dari hasil pekerjaannya sehingga mampu memenuhi kebutuhan hidup Pekerja/Buruh dan keluarganya secara wajar.Pasal 41 Ayat 1 Peraturan Pemerintah Nomor 78 Tahun 2015 tentang Pengupahan menyatakan Gubernur menetapkan upah minimum sebagai jaring pengaman. Pasal 43 Ayat 1 Peraturan Pemerintah Nomor 78 Tahun 2015 tentang Pengupahan menyatakan pula penetapan upah minimum sebagai dimaksud dalam Pasal 41 dilakukan setiap tahun beradasarkan Kebutuhan Hidup Layak (KHL) dan dengan memperhatikan produktivitas dan pertumbuhan ekonomi.

Salah satu cara yang dilakukan pekerja dalam mempertahankan haknya berupa upah adalah melakukan negosiasi atau berunding kepada pengusaha. Pengusaha dapat menerima maupun menolak negosiasi ataupun perundingan yang dilakukan oleh pekerja, dengan alasan bahwa pengusaha akan mengalami kerugian jika upah pekerja dinaikan, di lain pihak pekerja sangat membutuhkan kenaikan upah untuk memenuhi kehidupan keluarganya sehari-hari.

Pekerja dalam mempertahankan hak-haknya untuk di dengar oleh pengusaha tidak dapat dilakukan sendiri, para buruh membentuk sebuah organisasi atau serikat buruh, dimana serikat buruh dilindungi oleh Undang-Undang. Dibentuknya serikat buruh diharapkan hak-hak para buruh di dengar oleh pengusaha. Pasal 4 Ayat 1 Undang-Undang No. 21 Tahun 2000 tentang Serikat Pekerja/Serikat Buruh menyatakan bahwa serikat pekerja/serikat buruh, federasi, dan konfederasi serikat pekerja/serikat buruh bertujuan memberikan perlindungan perlindungan,

\footnotetext{
${ }^{7}$ Anonim. "Gubernur Anies tetapkan upah minimum pokok DKI Jakarta" http://news.liputan6.com, 01 November 2017.

${ }^{8}$ Anonim. "Berapa Upah Minimum DKI”, https://finance.detik.com, 30 Oktober 2017.
} 
pembelaan hak dan kepentingannya, serta meningkatkan kesejahteraan yang layak bagi buruh/pekerja dan keluarganya. ${ }^{9}$

Peran serikat pekerja sangat diperlukan untuk membantu pekerja dalam memperjuangkan hak-hak mereka, terutama dalam hal pengupahan. Hal ini disebabkan karena lemahnya peran pekerja dan kurangnya koordinasi antara buruh dengan manajemen perusahaan. Oleh karena itu serikat pekerja dibutuhkan untuk menyelesaikan perselisihan tersebut. Salah satu fungsi serikat pekerja dalam meningkatkan kesejahteraan pekerja adalah sebagai pihak dalam pembuatan perjanjian kerja bersama dan penyelesaian perselisihan industrial. ${ }^{10}$ Diharapkan dengan adanya perjanjian kerja bersama antara pihak pengusaha dengan pihak pekerja diharapkan dapat terciptanya hubungan kerja yang harmonis.

Berdasarkan uraian latar belakang tersebut, maka Penulis tertarik untuk melakukan kajian lebih lanjut secara komperehensif dan menuangkannya dengan judul "Bagaimana Peran Serikat Pekerja Dalam Penentuan Upah Setelah Berlakunya Peraturan Pemerintah No. 78 Tahun 2015 Tentang Pengupahan”.

\section{B. Permasalahan}

Berdasarkan latar belakang sebagaimana diuraikan di atas, permasalahan yang dikaji dalam artikel ini adalah:

1. Bagaimana peran serikat pekerja di Indonesia dalam penentuan upah di Jawa Barat?

2. Bagaimana peran serikat pekerja dalam penyusunan Perjanjian Kerja Bersama di perusahaan?

\section{II.PEMBAHASAN}

\section{A. Peran Serikat Pekerja Di Indonesia Dalam Penentuan Upah Di Jawa Barat}

\footnotetext{
${ }^{9}$ Indonesia, Undang-Undang Nomor 21 tahun 2000 tentang Serikat Pekerja/Serikat Buruh, Pasal 4 ayat 1 .

${ }^{10}$ Indonesia, Undang-Undang Nomor 21 tahun 2000 tentang Serikat Pekerja/Serikat Buruh, Pasal 4 ayat 2.
} 
Sebelum diberlakukanya Peraturan Pemerintah No. 78 Tahun 2015 tentang Pengupahan, serikat pekerja mempunyai peranan dalam penentuan upah minimum, upah minimum yang diatur dalam Pasal 89 Ayat 1 Undang-Undang No. 13 Tahun 2003 tentang Ketenagakerjaan menyatakan bahwa upah minimum sebagaimana dimaksud dalam Pasal 88 Ayat 3 huruf a dapat terdiri atas upah minimum berdasarkan provinsi atau kabupaten/kota dan upah minimum berdasarkan sektor pada wilayah provinsi atau kabupaten kota.

Ketentuan lebih lanjut mengenai penetapan upah minimum diatur di dalam Pasal 89 Ayat 3 Undang-Undang No. 13 Tahun 2003 tentang Ketenagakerjaan menyatakan bahwa upah minimum sebagaimana dimaksud dalam Ayat 1 ditetapkan oleh Gubernur dengan memperhatikan rekomendasi dari Dewan Pengupahan Provinsi dan/atau Bupati/Walikota. Pasal 98 Ayat 2 Undang-Undang No. 13 Tahun 2003 tentang Ketenagakerjaan menyatakan bahwa keaggotaan Dewan Pengupahan sebagaimana dimaksud dalam Ayat 1 terdiri dari unsur Pemerintah, organisasi pengusaha, serikat pekerja/serikat buruh, perguruan tinggi, dan pakar. Sehingga dalam Undang-Undang No. 13 Tahun 2003 tentang Ketenagakerjaan menegaskan bahwa penentuan upah minimum ditentukan oleh Dewan Pengupahan yang terdiri dari unsur Pemerintah, organisasi pengusaha, serikat pekerja, perguruan tinggi, dan pakar. Dewan Pengupahan mempunyai tugas yaitu merundingkan.

a) Dari data yang diperoleh penulis berdasarkan 3 (tiga) buah Perjanjian Kerja Bersama yang dilakukan antara pengusaha dengan serikat pekerja pada perusahaan yang berlokasi di daerah Jawa Barat dapat diketahui bahwa sejak diberlakukannya Peraturan Pemerintah Nomor 78 Tahun 2015 tentang Pengupahan, peran Serikat Pekerja dalam penentuan upah menjadi berkurang atau dibatasi. Pada Perjanjian Kerja Bersama PT Tokai Dharma Indonesia dengan PUK SPKEP SPSI, yang berlaku tahun 2017-2019 pada pasal $29^{11}$ disebutkan bahawa penyesuaian gaji/upah secara umum diperhitungkan

\footnotetext{
${ }^{11}$ Perjanjian Kerja Bersama Antara PT Tokai Dharma Indonesia dengan Pimpinan Unit Kerja Serikat Pekerja Kimia, Energi dan Pertambangan (PUK SPKEP SPSI) Pasal 29.
} 
pada setiap tahun dan besaran angka penyesuaian akan dirundingkan antara perusahaan dan serikat pekerja didasarkan atas angka inflasi atau index harga konsumsi dengan tetap memperhatikan kondisi dan kemampuan perusahaan pada saat itu. Hal tersebut dilanjutkan dengan apabila perusahaan memandang seseorang pekerja memberikan hasil kerja yang sangat baik dan menguntungkan perusahaan, maka perusahaan dapat memberikan kenaikan gaji bagi pekerja tersebut. Kenaikan atas penilaian prestasi, pekerja bisa diberikan kenaikan yang didasarkan semata-mata atas prestasi kerja pekerja yang bersangkutan. Penilaian prestasi pekerja dilakukan oleh perusahaan yang diadakan dengan kriteria tertentu sesuai dengan kebutuhan penilaian kerja pekerja yang bersangkutan. Berdasarkan Pasal dalam Perjanjian Kerja Bersama tersebut jelas bahwa peran Serikat Pekerja, walaupun terdapat perundingan, namun perundingan tersebut dilakukan dalam penentuan upah ditentukan berdasarkan angka inflasi atau index harga konsumsi dengan tetap memperhatikan kondisi dan kemampuan perusahaan yang bersangkutan termasuk dalam hal kenaikan gaji juga ditentukan oleh perusahaan berdasarkan prestasi kerja. Untuk meningkatkan produktivitas dan motivasi kerja perusahaan akan memberlakukan skala upah dan pelaksanaannya dilakukan secara bertahap, hal ini sesuai dengan isi dari Peraturan Pemerintah Nomor 78 Tahun 2015 tentang Pengupahan di mana perusahaan akan memberlakukan skala upah.

Berdasarkan data Perjanjian Kerja Bersama PT Triple Ace Corporation ${ }^{12}$ yang menyebutkan bahwa besar-kecilnya kenaikan upah akan disesuaikan dengan

\footnotetext{
${ }^{12}$ Perjanjian Kerja Bersama Antara PT Triple Ace Corporation dengan Serikat Pekerja Kimia, Energi dan Pertambangan Serikat Pekerja Seluruh Indonesia(PUK SPKEP SPASI) Pasal 35.
} 
mempertimbangkan hal-hal yaitu standar Upah Minimum Sektoral Kota setempat, keadaan perekonomian Negara pada umumnya, hasil evaluasi prestasi kerja, kemampuan perusahaan yang dilandasi dengan adanya kesepakatan PUK dan PT Triple Ace Corporation dan Attitude pekerja, maka dari kalimat dalam pasal tersebut tidak terdapat adanya perundingan bipartite di antara para pihak sebagai syarat dalam menentukan upah maupun kenaikan upah. Kenaikan upah/gaji pada PT Triple Ace Corporation akan diberikan kepada Pekerja Tetap (Permanent) berdasarkan ketentuan dan kriteria yang diatur oleh manajemen sebagai berikut: perubahan Job Class golongan A ke golongan B maksimum 18 (delapan belas) bulan, kenaikan upah/gaji berdasarkan prestasi kerja perorangan dari golongan B ke golongan $\mathrm{C}$ (lihat lampiran upah/gaji), dan kenaikan upah/gaji berdasarkan prestasi kerja umum yang mana erat kaitannya dengan peningkatan efisiensi dan penurunan scrap secara menyeluruh. Berdasarkan aturan mengenai kenaikan upah di PT Triple Ace Corporation, maka jelas diatur bahwa kenaikan upah ditentukan oleh perusahaan berdasarkan prestasi kerja karyawan, tidak terdapat sama sekali peran Serikat Pekerja untuk berunding tentang kenaikan upah di perusahaan.

Data ketiga dari Perjanjian Kerja Bersama PT Energizer Indonesia ${ }^{13}$, menyebutkan Penetapan pengupahan didasarkan atas "Clean Wage System" dengan ketentuan upah/gaji 1 (satu) jam sama dengan 1/173 (seperseratus tujuh puluh tiga) upah/gaji dasar kotor sebulan. Sistem pengupahan terdiri dari 2 (dua) struktur upah yaitu: struktur upah/gaji untuk pekerja "Hourly", termasuk dalam golongan ini adalah mechanic, driver, production operator dan sebagainya serta

\footnotetext{
${ }^{13}$ Perjanjian Kerja Bersama Antara PT. Energizer Indonesia dengan SP, KEP Unit Kerja PT. Energizer Indonesia Pasal 26
} 
struktur upah/gaji untuk pekerja "Salaried - Non Excempt (Clerical)", termasuk dalam golongan ini adalah pekerja administrasi bukan pengawas, misalnya Clerk, Typist, Receptionist dan sebagainya. Pada PKB PT Enegizer Indonesia, jelas digambarkan bahwa penentuan upah minimum ditetapkan berdasarkan struktur skala upah, hal mana sesuai dengan apa yang ditetapkan dalam Peraturan Pemerintah Nomor 78 Tahun 2015 tentang Pengupahan.

Pada PT Enegizer Indonesia, diatur pula tiap Struktur upah/gaji mempunyai tingkat upah/gaji yang dilakukan dan setiap pekerja mempunyai tingkat upah menurut kedudukannya dalam perusahaan.

Berdasarkan hasil wawancara bersama Mohammad Fandrian Hadistianto ${ }^{14}$, dan Mustiyah $^{15}$ dengan kemunculannya Peraturan Pemerintah No. 78 Tahun 2015 tentang Pengupahan merombak semua proses penetapan upah minimum untuk seluruh wilayah Indonesia. Implikasinya semenjak adanya Peraturan Pemerintah No. 78 Tahun 2015 tentang Pengupahan, dewan pengupahan yang terdiri dari unsur Pemerintah, organisasi pengusaha, serikat pekerja/serikat buruh, perguruan tinggi, dan pakar, menjadi tidak berfungsi lagi karena upah minimum ditentukan oleh Pemerintah dengan menggunakan rumusan penentuan upah minimum yang terdiri dari upah minimum tahun berjalan, inflasi dan produk domestik bruto. Sehingga serikat pekerja mengajukan uji materiil mengenai Peraturan Pemerintah No.78 Tahun 2015 tentang Pengupahan terhadap Undang-Undang No. 13 Tahun 2003 tentang Ketenagakerjaan, akan tetapi tidak dapat diterima dikarenakan Undang-Undang No. 13 Tahun 2003 tentang Ketenagakerjaan sampai saat ini masih dalam proses uji materiil di Mahkamah Agung. Berdasarkan hasil

\footnotetext{
${ }^{14}$ Peneliti, Wawancara, dengan Advokat/Wakil Direktur Lembaga Bantuan Hukum Pimpinan Pusat Serikat Pekerja Kimia, Energi dan Pertambangan Serikat Pekerja Seluruh Indonesia, 5 Juni 2018).

${ }^{15}$ Peneliti, Wawancara, dengan Ketua Bid. Perempuan dan Sosek, (Jakarta: Sekretariat Pimpinan Pusat Serikat Pekerja Kimia, Energi dan Pertambangan Serikat Pekerja Seluruh Indonesia, 5 Juni 2018).
} 
wawancara bersama Bapak Faisal Rizza ${ }^{16}$ mempunyai pendapat berbeda mengenai Undang-Undang No. 13 Tahun 2003 tentang Ketenagakerjaan, dimana dalam proses survei pasar yang dilakukan antara dewan pengupahan, serikat pekerja, dan pengusaha sering kali tidak sama dalam menentukan objek pasar, dikarenakan pihak dewan pengupahan, serikat pekerja, dan pengusaha sering kali melakukan survei pasar yang berbeda dalam menentukan kehidupan yang layak bagi pekerja. Penulis berpendapat bahwa peran serikat pekerja terutama dalam meningkatkan kesejahteraan pekerja dalam proses penentuan upah menjadi tidak berfungsi kembali setelah berlakunya Peraturan Pemerintah No. 78 Tahun 2015 tentang Pengupahan, akan tetapi penulis berpendapat sama dengan Bapak Faisal Rizza bahwa dengan diberlakukannya Peraturan Pemerintah No. 78 Tahun 2015 tentang Pengupahan tidak perlu lagi dilakukannya proses berunding untuk menetapkan upah Kabupaten/Kota.

Tujuan diterbitkannya Peraturan Pemerintah No. 78 Tahun 2015 tentang Pengupahan adalah Pemerintah ingin mengembalikan kebijakan mengenai upah minimum pada jalannya, yaitu melalui perundingan Bipartit sebagai jaring pengaman dan mewajibkan perusahaan untuk menerapkan struktur dan skala upah. Struktur skala upah wajib disusun oleh pengusaha dalam memperhatikan golongan, jabatan, masa kerja, pendidikan, dan konpensasi. Penyusunan struktur sekala upah dimaksudkan sebagai pedoman penetapan upah sehingga terhadap kepastian upah tiap pekerja serta untuk mengurangi kesenjangan antara upah terendah dan tertinggi pada perusahaan yang bersangkutan. Selain itu fungsi struktur skala upah yang diatur di dalam Pasal 14 Ayat 4 Peraturan Pemerintah No. 78 Tahun 2015 tentang Pengupahan adalah merupakan prasayarat dalam pengesahan dan pembaruan Peraturan Perusahaan serta pendaftaran, perpanjangan, dan pembaruan Perjanjian Kerja Bersama.

Struktur dan skala upah wajib diberitahukan kepada seluruh pekerja atau buruh. Apabila pengusaha tidak membuat struktur skala upah, maka akan dikenakan

\footnotetext{
${ }^{16}$ Peneliti, Wawancara, dengan Kasi Penanganan Mogok Kerja dan Penutupan Perusahaan Kementerian Ketenagakerjaan Republik Indonesia, (Jakarta: Kementerian Ketenagakerjaan Republik Indonesia, 22 Maret 2018).
} 
sanksi administratif, sanksi administratif dapat berupa teguran tertulis, pembatasan kegiatan usaha, penghentian sementara sebagian atau seluruh alat produksi, pembekuan kegiatan usaha.

Upah minimum dilaksanakan untuk pekerja yang bekerja selama 0 - 1 Tahun atau pekerja lajang. Apabila para pekerja bekerja lebih dari 1 Tahun atau telah menikah maka pekerja memiliki hak atas peningkatan upah. Peningkatan upah tersebut harus dibuat tertulis dengan musyawarah oleh perusahaan dengan dibantu oleh serikat pekerja, hasil dari musyawarah tersebut adalah perundingan, naum dengan adanya Peraturan Pemerintah No.78 Tahun 2015 tentang Pengupahan maka upah ditetapkan dalam struktur skala upah bukan dalamperundingan.

\section{B. Peran Serikat Pekerja Dalam Penyusunan Perjanjian Kerja Bersama} Di PerusahaanAkibat Hukum Terhadap Pekerja Yang Diputus Hubungan

Perjanjian kerja bersama yang penulis gunakan sebagai data untuk dianalisis dalam penelitian skripsi (terutama yang penulis bahas adalah bagian pengupahan). Sebagai berikut:

1. Perjanjian Kerja Bersama antara PT. Tokai Dharma Indonesia dengan Pimpinan Unit Kerja Serikat Pekerja Kimia, Energi, dan Pertambangan (PUK SPKEP SPSI). PT Tokai Dharma Indonesia, Periode 2017-2019.

a Mengenai ketentuan umum ${ }^{17}$

1) Komponen upah yang digunakan oleh perusahaan PT. Tokai Dharma Indonesia berdasarkan kesepakatanbersama dengan PUK SPKEP SPSI adalah:

a) Gaji pokok

b) Tunjangan Jabatan yang diberikan kepada pekerja dengan ketentuan:

(1) Pekerja tersebut menduduki posisi atau jabatan tertentu;

\footnotetext{
${ }^{17}$ Periode 2017-2019, Perjanjian Kerja Bersama Antara PT Tokai Dharma Indonesia dengan Pimpinan Unit Kerja Serikat Pekerja Kimia, Energi dan Pertambangan (PUK SPKEP SPSI) Pasal 28
} 
(2) Tunjangan jabatan yang diberikan dapat dicabut apabila yang bersangkutan sudah tidak menduduki posisi tertentu atau tidak menjabat lagi diperusahaan tersebut;

(3) Tunjangan jabatan yang diberikan oleh perusahaan merupakan komponen upah;

(4) Tunjangan jabatan yang diberikan oleh perusahaan kepada pekerja yang telah mempunyai status tetap;

(5) Terdapat beberapa besaran tunjangan jabatan, diantaranya:

Tunjangan golongan 1 yaitu Cleaning Service, kenek, helpermendapatkan tunjangan sebesaar Rp.30.000.-, Tunjangan untuk golongan 2 yaituoperator mesin, pengemudi, petugas gudang, koperasi, P2K3 dan setaranya mendapatkan tunjangan sebesar Rp.40.000.-, Tunjangan golongan 3A yaitu staff admin, utility, satpam, salesman dan setaranya mendapatkan tunjangan sebesar Rp. 52.500.-, tunjangan untuk golongan 3B yaitu Kepala Kelompok (KK), maintenance, Qc, Moldshop mendapatkan tunjangan sebesar Rp.65.000.-

2) Pembayaran upah yang digunakan oleh PT. Tokai Dharma Indonesia untuk para pekerjanya adalah sebagai berikut:

a) Pembayaran upah untuk pekerja bulanan Upah dibayarkan oleh perusahaan kepada pekerja paling lambat sehari sebelum bulan berjalan berakhir. Apabila tanggal jatuh pada hari libur maka pembayaran dilakukan pada hari kerja terakhir sebelum tanggal tersebut.

b) Pembayaran upah untuk pekerja dengan masa percobaan Selama masa percobaan, gaji yang bersangkutan ditetapkan sebesar $80 \%$ dari gaji pokok yang diterimakan dengan 
ketentuan tidak kurang dari Upah Minimum Kota (UMK).

Setelah pekerja tersebut melampaui masa percobaan, secara otomatis yang bersangkutan mendapatkan gaji sesuai tingkat gaji yang telah ditetapkan oleh perusahaan.

3) Periode perhitungan upah dimulai dari tanggal 23 bulan sebelumnya sampai dengan tanggal 22 bulan berjalan dan dibayarkan pada tanggal 25 setiap bulannya dengan cara ditransfer ke rekening bank yang bersangkutan.

b Mengenai Gaji atau Upah dan Kenaikan ${ }^{18}$

1) Gaji atau upah

Gaji atau upah adalah imbalan yang diberikan kepada pekerja menurut golongan/jabatannya di perusahaan berdasarkan latar belakang pendidikan dengan pengalaman kerja dan kriteria-kriteria lain yang dibutuhkan untuk jabatan tersebut.

2) Kenaikan gaji atau upah diantaranya:

a) Kenaikan atas penilaian prestasi, pekerja bisa diberikan kenaikan yang didasarkan semata-mata atas prestasi kerja pekerja yang bersangkutan. Penilaian prestasi pekerja dimaksud dalam ayat 1 dilakukan oleh perusahaan yang diadakan dengan kriteria tertentu sesuai dengan kebutuhan penilaian kerja pekerja yang bersangkutan;

b) Kenaikan upah pekerja dapat berupa kenaikan gaji pokok dan atau perubahan tunjangan-tunjangan lainnya;

c) Penyesuaian gaji atau upah secara umum diperhitungkan pada setiap tahun. Besar angka penyesuaian akan dirundingkan antara perusahaan dan serikat pekerja didasarkan atas angka inflasi atau index harga konsumsi dengan tetap memperhatikan kondisi dan kemampuan perusahaan pada saat itu;

d) Bila perusahaan memandang seseorang pekerja emberikan hasil kerja yang sangat baik dan menguntungkan perusahaan, maka perusahaan dapat memberikan kenaikan

18 Periode 2017-2019, Perjanjian Kerja Bersama Antara PT Tokai Dharma Indonesia dengan Pimpinan Unit Kerja Serikat Pekerja Kimia, Energi dan Pertambangan (PUK SPKEP SPSI) Pasal 29. 
gaji bagi pekerja tersebut tanpa menyimpangi dari jadwal tahunan.

3) Untuk meningkatkan produktivitas dan motivasi kerja perusahaan akan memberlakukan skala upah dan pelaksanaannya dilakukan secara bertahap.

c Mengenai Fasilitas Makan ${ }^{19}$

Perusahaan memberikan fasilitas makan kepada pekerja pada jam istirahat, hal yang berkaitan dengan hal tersebut diatur pada peraturan pelaksanaan. Fasilitas makan dapat diberikan oleh perusahaan dalam bentuk sajian makan bagi pekerja maupun pengganti uang makan kepada pekerja yang bekerja di luar perusahaan.

d Mengenai Tunjangan Hari Raya ${ }^{20}$

Tunjangan Hari Raya (THR) berdasarkan Permenaker No. 04/Men/1994 yang diatur sebagai berikut:

1) Pekerja yang telah lewat masa kerja 1 (satu) tahun, besarnya 1 (satu) kali gaji sebulan. Bagi pekerja yang telah melewati masa percobaam akan tetapi masa kerjanya belum mencapai 1 (satu) tahun, diberikan Tunjangan Hari Raya menurut perhitungan X/12 dari gaji sebulan (X merupakan masa kerja dalam bulan yang telah dilakukan oleh pekerja).

2) Tunjangan Hari Raya diberikan kepada pekerja paling lambat 2 (dua) minggu sebelum Hari Raya yang diberikan dimulai.

3) Pekerja yang putus hubungan kerja 30 hari sebelum Hari Raya berhak atas Tunjangan Hari Raya dan dihitung secara prorata.

e Mengenai Mengenai Tunjangan Istimewa Tahunan ${ }^{21}$

1) Perusahaan akan memberikan tunjangan istimewa tahunan kepada pekerja pada setiap akhir tahun dan besarnya tunjangan istimewa tahunan dengan melihat kondisi perusahaan dan sekecil-kecilnya

\footnotetext{
${ }^{19}$ Periode 2017-2019, Perjanjian Kerja Bersama Antara PT Tokai Dharma Indonesia dengan Pimpinan Unit Kerja Serikat Pekerja Kimia, Energi dan Pertambangan (PUK SPKEP SPSI) Pasal 31 ${ }^{20}$ Periode 2017-2019, Perjanjian Kerja Bersama Antara PT Tokai Dharma Indonesia dengan Pimpinan Unit Kerja Serikat Pekerja Kimia, Energi dan Pertambangan (PUK SPKEP SPSI) Pasal 31 ${ }^{21}$ Periode 2017-2019, Perjanjian Kerja Bersama Antara PT Tokai Dharma Indonesia dengan Pimpinan Unit Kerja Serikat Pekerja Kimia, Energi dan Pertambangan (PUK SPKEP SPSI) Pasal 32
} 
menerima presentasi dari upah sebulan yang akan ditetapkan sesuai dengan kondisi keuangan perusahaan pada saat itu.

2) Pekerja yang putus hubungan kerja 30 hari sebelum pembayaran Tunjangan Istimewa Tahunan tidak berhak mendapatkannya.

3) Bagi pekerja yang mengundurkan diri 30 hari sebelum hari diberikannya Tunjangan Istimewa mendapat Tunjangan istimewa Tahunan secara prorata

f Mengenai Tunjangan Sakit ${ }^{22}$

1) Pekerja yang menderita sakit untuk masa yang cukup lama dan terus-menerus akan menerima tunjangan sakit dari perusahaan sebagai pengganti gaji. Dengan mengacu pada Pasal 93 Ayat 3 Undang-Undang No. 13 Tahun 2003 tentang Ketenagakerjaan yang menyatakan untuk 4 (empat bulan pertama, dibayar 100\% (seratus perseratus) dari upah, untuk 4 (empat) bulan kedua, dibayar 75\% (tujuh puluh lima perseratus) dari upah, untuk 4 (empat) bulan ketiga, dibayar 50\% lima puluh perseratus) dari upah; dan untuk bulan selanjutnya dibayar $25 \%$ (dua puluh lima perseratus) dari upah sebelum pemutusan hubungan kerja dilakukan oleh pengusaha.

2) Pekerja yang mengalami sakit berkepanjangan, mengalami cacat akibat kecelakaan kerja dan tidak dapat melakukan pekerjaannya setelah melampaui waktu 12 (dua belas) bulan perusaan dapat melakukan pemutusan hubungan kerja.

g Mengenai Upah Pekerja Selama Skorsing ${ }^{23}$

Pekerja yang dikenakan tindakan skorsing, upahnya dibayarkan 100\% sejak pekerja diskorsing pada bulan yang bersangkutan sampai saat persoalannya diajukan kepada yang berwenang. Pekerja yang dalam

\footnotetext{
22 Periode 2017-2019, Perjanjian Kerja Bersama Antara PT Tokai Dharma Indonesia dengan Pimpinan Unit Kerja Serikat Pekerja Kimia, Energi dan Pertambangan (PUK SPKEP SPSI) Pasal 33

${ }_{23}$ Periode 2017-2019, Perjanjian Kerja Bersama Antara PT Tokai Dharma Indonesia dengan Pimpinan Unit Kerja Serikat Pekerja Kimia, Energi dan Pertambangan (PUK SPKEP SPSI) Pasal 34
} 
proses pemutusan hubungan kerja perusahan wajib membayar upah beserta hak-hak hang biasa diterima pekerja.

Skorsing adalah:

1) Dilaksanakan apabila pekerja yang sudah pernah mendapat peringatan tertulis III dan masih melakukan pelanggaran.

2) Dilaksanakan terhadap pekerja yang dalam taraf penyelesaian kasusnya dengan perusahaan yang menjurus ke pemutusan hubungan kerja.

3) Diberikan kepada pekerja dalam rangka menunggu penyelesaian kasus pemutusan hubungan kerjanya berdasarkan Undang-Undang No. 2 Tahun 2004 tentang penyelesaian perselisihan hubungan industrial.

h Mengenai Upah Pekerja Selama Ditahan oleh Alat Kekuasaan Negara $^{24}$

1) Perusahaan tidak berkewajiban untuk membayar upah kepada pekerja selama ditahan oleh Alat Kekuasaan Negara, bukan karena pengaduan oleh perusahaan, tetapi wajib memberikan bantuan kepada keluarga yang menjadi tanggungannya, yaitu untuk 1 (satu) orang tanggungan: 25\% dari upah, untuk 2 (dua) orang tanggungan: $35 \%$ dari upah, untuk 3 (tiga) orang tanggungan: $45 \%$ dari upah, untuk 4 (empat) orang tanggungan: 50\% dari upah.

2) Lamanya pemberian bantuan paling lama 6 (enam) bulan terhitung sejak pertama bekerja ditahan pihak berwajib. Apabila penahanan pekerja berdasarkan tuduhan pengusaha dan ternyata tidak terbukti melakukan kesalahan, maka pengusaha wajib mempekerjakan pekerja kembali dengan membayar upah penuh serta hal lainnya yang seharusnya diterima pekerja terhitung pekerja ditahan pihak berwajib.

${ }^{24}$ Periode 2017-2019, Perjanjian Kerja Bersama Antara PT Tokai Dharma Indonesia dengan Pimpinan Unit Kerja Serikat Pekerja Kimia, Energi dan Pertambangan (PUK SPKEP SPSI) Pasal 35 
3) Mengenai hal pekerja ditahan atas pengaduan pengusaha, selama izin pemutusan hubungan kerja belum diberikan, maka perusahaan wajib memberikan upah sebesar $75 \%$ terhitung sejak pertama kali pekerja ditahan.

4) Tunjangan tidak berlaku, apabila keputusan hakim/pengadilan menetapkan pekerja tersebut bersalah karena melakukan tindakan kriminal/subversi.

i Mengenai Pembayaran Upah/Gaji Sehubungan dengan Pemindahan Dinas/Lokasi Kerja ${ }^{25}$

Pada dasarnya pemindahan pekerja yang dilakukan tidak mengurangi pendapatan pekerja, kecuali bila dalam hal pekerja yang dipindahkan ke jabatan yang lebih rendah disebabkan karena ketidak mampuan/ketidak cakapan atau karena tindakan indisipliner maka upah/gajinya disesuaikan dengan upah/gajinya untuk kelas jabatan yang baru.

j Mengenai Premi Hadir/Insentif ${ }^{26}$

Pekerja tetap untuk golongan I sampai dengan IV dan pekerja kontrak, tidak mengurangi jam kerja lebih dari 60 (enam puluh) menit dalam satu hari, maka kepadanya diberikan premi hadir sebesar Rp. 85.000.(delapan puluh lima ribu rupiah) per bulan.

k Mengenai Tunjangan Uang Transportasi ${ }^{27}$

1) Perusahaan wajib memberikan tunjangan transport kepada pekerja tetap yang tidak memperoleh fasilitas kendaraan atau antar jemput dari dan ke tempat kerja, sebesar Rp. 110.000.- per bulan bagi golongan I sampai dengan IV.

2) Tunjangan Transport merupakan komponen upah dan menjadi komponen perhitungan lembur, THR, bonus, kenaikan upah, BPJS

\footnotetext{
${ }^{25}$ Periode 2017-2019, Perjanjian Kerja Bersama Antara PT Tokai Dharma Indonesia dengan Pimpinan Unit Kerja Serikat Pekerja Kimia, Energi dan Pertambangan (PUK SPKEP SPSI) Pasal 36 ${ }^{26}$ Periode 2017-2019, Perjanjian Kerja Bersama Antara PT Tokai Dharma Indonesia dengan Pimpinan Unit Kerja Serikat Pekerja Kimia, Energi dan Pertambangan (PUK SPKEP SPSI) Pasal 37 ${ }^{27}$ Periode 2017-2019, Perjanjian Kerja Bersama Antara PT Tokai Dharma Indonesia dengan Pimpinan Unit Kerja Serikat Pekerja Kimia, Energi dan Pertambangan (PUK SPKEP SPSI) Pasal 38
} 
Ketenagakerjaan, pengobatan dan dana pensiun berlaku pada PKB - XIV.

3) Tunjangan transport selebihnya setelah Rp. 110.000.- disebut bantuan uang transport dan bukan merupakan tunjangan tetap, tetapi berdasarkan kehadiran.

4) Pekerja yang mendapat kendaraan operasional tidak mendapat bantuan uang transport selebihnya dari Rp. 110.000.-

5) Apabila adanya kenaikan biaya transportasi maka secara otomatis perusahaan akan menaikan bantuan uang transport berdasarkan persentasi kenaikan ongkos transportasi umum di Depok.

2. Perjanjian Kerja Bersama Antara PT. Energizer Indonesia dengan SP. KEP Unit Kerja PT. Energizer Indonesia Periode 2016 - 2018

a Mengenai penetapan pengupahan ${ }^{28}$

1) Penetapan pengupahan didasarkan atas "Clean Wage System" dengan ketentuan upah/gaji 1 (satu) jam sama dengan 1/173 (seperseratus tujuh puluh tiga) upah/gaji dasar kotor sebulan.

2) Sistem pengupahan terdiri dari 2 (dua) struktur upah yaitu:

a) Struktur upah/gaji untuk pekerja "Hourly", termasuk dalam golongan ini adalah mechanic, driver, production operator dan sebagainya.

b) Struktur upah/gaji untuk pekerja "Salaried - Non Excempt (Clerical)", termasuk dalam golongan ini adalah pekerja administrasi bukan pengawas, misalnya Clerk, Typist, Receptionist dan sebagainya.

Tiap Struktur upah/gaji mempunyai tingkat upah/gaji yang dilakukan dan setiap pekerja mempunyai tingkat upah menurut kedudukannya dalam perusahaan.

${ }^{28}$ Periode 2016-2018 , Perjanjian Kerja Bersama Antara PT. Energizer Indonesia dengan SP, KEP Unit Kerja PT. Energizer Indonesia Pasal 26. 
3) Sejak ditandatangani Perjanjian Kerja Bersama ini, maka berlaku skala upah/gaji sebagai terlampir (lampiran VII), yang tidak terpisah dengan Perjanjian Kerja Bersama ini.

4) Peninjauan/penyesuaian upah/gaji dilakukan setelah 12 (dua belas) bulan sekali dengan ketentuan sebagai berikut:

a) Terhitung mulai 11 April 2016 sampai dengan tanggal 10 Desember 2016 untuk Pekerja Hourly dan untuk Pekerja Salaried Non-Exempt (Clerical) kenaikan upah/gaji ditentukan sebesar Rp. 400.000 (Empat ratus ribu rupiah) untuk operator dan Rp. 410.000 (Empat ratus sepuluh ribu rupiah) untuk Mechanic.

b) Selanjutnya peninjauan/penyesuaian upah/gaji untuk periode: Januari 2017 sampai dengan Desember 2017 untuk Pekerja Hourly dan untuk Pekerja Non-Exempt (Clerical), didasarkan kepada perubahan laju inflasi Indeks Harga Konsumen untuk DKI Jakarta bulan Januari 2016 sampai dengan Desember 2016 ditambah $1 \%$ (satu persen) ditambah lagi OAE.2 dengan kenaikan minimum 9\% (Sembilan persen) dan maksimum 20\% (dua puluh persen).

5) Kenaikan upah/gaji akan diberikan kepada Pekerja Tetap (Permanent) berdasarkan ketentuan dan kriteria yang diatur oleh manajemen sebagai berikut:

a) Perubahan Job Class golongan A ke golongan B maksimum 18 (delapan belas) bulan.

b) Kenaikan upah/gaji berdasarkan prestasi kerja perorangan dari golongan B ke golongan C (lihat lampiran upah/gaji).

c) Kenaikan upah/gaji berdasarkan prestasi kerja umum yang mana erat kaitannya dengan peningkatan efisiensi dan penurunan scrap secara menyeluruh. 
6) Pekerja junior akan beralih status menjadi pekerja senior pada saat 1 (satu) tahun setelah pengangkatan menjadi pekerja tetap.

b Mengenai pembayaran upah/gaji ${ }^{29}$

1) Untuk pekerja "Hourly" dilakukan pada setiap hari kerja terakhir dari setiap bulan takwim, dimana setiap tanggal 10 (sepuluh) bulan takwim berjalan atau sebelumnya bila tanggal tersebut jatuh pada Hari Raya/Istiralah mingguan akan diberikan uang muka 50\% (lima puluh persen) dari upah/gaji pokok. Pembayaran ini mencakup jangka waktu pembayaran dari tanggal 11 (sebelas) bulan takwim yang lalu sampai dengan tanggal 10 (sepuluh) bulan takwim yang berjalan.

2) Untuk pekerja "Salaried Non-Exempt" dilakukan pada tanggal 25 setiap bulan takwim atau sebelumnya bila pembayaran tersebut jatuh pada Hari Raya/Istirahat mingguan.

3) Semua pekerja akan menerima resi pembayaran bersamaan dengan penerimaan gaji/upahnya. Resi pembayaran berisi datadata jumlah upah/gaji yang diterima, tambahan-tambahan, tagihan yang ada, dan sebagainya.

c Mengenai pembayaran upah kerja lembur ${ }^{30}$

Pembayaran upah kerja lembur akan dilakukan dengan berpedoman kepada Peraturan Perundang-Undangan yang berlaku.

d Pembayaran upah/gaji selama penugasan sementara ${ }^{31}$

1) Dalam hl seorang pekerja "Hourly" untuk sementara harus menggantikan pekerjaan seseorang dari kelas jabatan yang lebih tinggi untuk jangka waktu sekurang-kurangnya 4 (empat) jam secara terus-menrus tanpa terputus, pembayaran upahnya disesuaikan dengan upah dari jabatan yang lebih tinggi

\footnotetext{
${ }^{29}$ Perjanjian Kerja Bersama Antara PT. Energizer Indonesia dengan SP, KEP Unit Kerja PT. Energizer Indonesia Pasal 27.

${ }^{30}$ Perjanjian Kerja Bersama Antara PT. Energizer Indonesia dengan SP, KEP Unit Kerja PT. Energizer Indonesia Pasal 28.

${ }^{31}$ Perjanjian Kerja Bersama Antara PT. Energizer Indonesiadengan SP, KEP Unit Kerja PT. Energizer Indonesia Pasal 29.
} 
tersebut. Bila penugasan sementara itu mencakup jam-jam kerja lembur, pembayaran upah kerja lembur didasarkan pada upah dari jabatan yang lebih tinggi tersebut.

2) Bila penugasan sementara itu kurang dari 4 (empat) jam pembayaran tetap seperti pembayaran untuk kelas jabatannya sendiri.

3) Bila penugasan sementara pada kelasan jabatan yang lebih rendah, maka pembayaran tetap seperti pembayaran untuk kelas jabatannya sendiri.

4) Penugasan sementara ini harus diberitahu secara tertulis kepada yang bersangkutan dan masa penugasan tersebut tidak lebih dari 12 (dua belas) bulan.

5) Pembayaran ini tidak berlaku bagi pekerja sedang dalam masa "cross training".

6) Pengusaha wajib untuk membayar upah sebasar 4 (empat) jam lembur kepada pekerja yang bersedia melakukan pekerjaan lembur yang telah dijanjikan, tetapi pengusaha tidak mempekerjakannya baik karena kesalahan sendiri maupun halangan yang dialami oleh pengusaha yang seharusya dapat dihindari.

Perjanjian Kerja Bersama yang dirundingkan antara pihak pengusaha dan pihak serikat antara PT. Tokai Dharma Indonesia dengan Pimpinan Unit Kerja Serikat Pekerja Kimia, Energi dan Pertambangan (PUK SPKEP SPSI) dalam mensejahteran pekerjanya dengan melakukan proses pembuatan Perjanjian Kerja Bersama PT. Tokai Dharma Indonesia ternyata terdapat peran serikat pekerja dalam pembuatan perjanjian kerja bersama tersebut, dimana di dalam isi perjanjian kerja bersama dalam Pasal 28 Ayat 1 Huruf b yang menyatakan bahwa terdapatnya tunjangan jabatan yang diberikan kepada setiap pekerja yang menduduki posisi tertetu. 
Tunjangan jabatan tersebut merupakan komponen upah pokok dan tunjangan tetap sebagaimana yang diatur dalam Pasal 5 Ayat 1 Peraturan Pemerintah No. 78 Tahun 2015 tentang Pengupahan, dimana upah sebagaimana dimaksud dalam Pasal 4 Ayat 2 Huruf a terdiri atas komponen upah tanpa tunjangan, upah pokok dan tunjangan tetap, atau upah pokok, tunjangan tetap, dan tunjangan tidak tetap. Terdapat pula ketentuan yang sebagaimana dimaksud dalam Pasal 5 Ayat 4 Peraturan Pemerintah No. 78 Tahun 2015 tentang Pengupahan yang menyatakan bahwa upah sebagaimana dimaksud pada Ayat 1 diatur dalam perjanjian kerja, peraturan perusahaan, atau perjanjian kerja bersama. Tunjangan istimewa tahunan yang diatur dalam Pasal 32 di dalam perjanjian kerja bersama, yang telah sesuai dengan Pasal 8 Peraturan Pemerintah No. 78 Tahun 2015 tentang Pengupahan. Pembayaran upah/gaji sehubungan dengan pemindahan dinas atau lokasi kerja yang diatur di dalam pasal 36 Perjanjian Kerja Bersama PT. Tokai yang menyatakan pada dasarnya pemindahan pekerja yang dilakukan tidak mengurangi pendapatan pekerja, kecuali bila dalam hal pekerja yang dipindahkan ke jabatan yang lebih rendah disebabkan karena ketidak mampuan/ketidak cakapan atau karena tindakan indisipliner maka upah/gajinya disesuaikan dengan upah/gajinya untuk kelas jabatan yang baru, ketentuan mengenai pembayaran upah sehubungan dengan pemindahan dinas/lokasi kerja memang tidak diatur di dalam UndangUndang atau Peraturan Pemerintah, dikarenakan mengenai pembayaran upah sehubungan dengan pemindahan dinas/lokasi kerja tersebut merupakan bagian dari para pihak antara pengusaha dan serikat pekerja asalkan tidak bertentangan dengan syarat sahnya suatu perjanjian yang diatur di dalam Pasal 1320 KUHperdata. Premi hadir/Insentif diberikan kepada setiap pekerja dengan tujuan sebagai balas jasa atas tunduknya pada peraturan perusahaan yang berlaku. Tunjangan uang traportasi bisa merupakan tunjangan tetap dan tunjangan tidak tetap, dimana dalam perjanjian kerja bersama ini tunjangan uang transportasi masuk dalam komponen tunjangan tetap karena diberikan uang sebesar Rp. 110.000.- per bulan bagi setiap golongan, akan tetapi apabila melebihi Rp. 110.000.- masuk sebagai tunjangan tidak tetap yang berdasarkan kehadiran. 
Disamping terdapatnya peran serikat pekerja dalam pembuatan perjanjian kerja bersama PT. Tokai ternyata terdapat beberapa ketentuan yang tidak mempunyai peranan serikat pekerja dalam proses pembuatannya, seperti Tunjangan Hari Raya karena ketentuan mengenai Tunjangan Hari Raya pada dasarnya telah sesuai dengan Pasal 3 Ayat 1 Peraturan Menteri Ketenagakerjaan No. 6 Tahun 2016 tentang Tunjangan Hari Raya Keagamaan Bagi Pekerja/Buruh Di Perusahaan. Tunjangan Sakit dikarenakan tunjangan sakit tersebut telah sesuai dengan Pasal 26 Ayat 1 Peraturan Pemerintah No. 78 Tahun 2015 tentang Pengupahan. Upah pekerja selama skorsing dikarenakan telah sesuai dengan Pasal 155 Ayat 3 Undang-Undang No. 13 Tahun 2003 tentang Ketenagakerjaan. Upah pekerja selama ditahan oleh Alat Kekuasaan Negara dikarenakan telah sesuai dengan Pasal 160 Undang-Undang No. 13 Tahun 2003 tentang Ketenagakerjaan. Pajak penghasilan telah sesuai dengan Pasal 36 Ayat 1 Peraturan Pemerintah No. 78 Tahun 2015 tentang Pengupahan.

Sedangkan Perjanjian Kerja Bersama antara PT. Energizer Indonesia dengan SP. KEP. Unit Kerja PT. Energizer Indonesia, dalam mensejahteran pekerjanya dengan melakukan proses pembuatan Perjanjian Kerja Bersama PT. Enirgizer ternyata terdapat peran serikat pekerja dalam pembuatan perjanjian kerja bersama tersebut, dimana di dalam isi perjanjian kerja bersama dalam Pasal 26 Ayat 4 Huruf yang menyatakan bahwa terdapat beberapa kesepakatan yang dibuat antara pihak pengusaha dan pihak serikat pekerja meskipun perlu digaris bawahi bahwa PKB PT. Energizer berlaku sebelum terbitnya Peraturan Pemerintah No. 78 Tahun 2015 tentang Pengupahan yang dibuat antara pihak pengusaha dan pihak serikat pekerja, diantaranya Untuk pekerja bergaji perjam dan pekerja bergaji bulanan maka akan mendapatkan kenaikan upah sebesar Rp. 400.000.- untuk operator, sedangkan kenaikan gaji untuk mekanik akan mendapatkan kenaikan gaji sebesar Rp. 410.000.- terhitung mulai 11 April 2016 sampai dengan tanggal 10 Desember 2016. Selanjutnya untuk periode Januari 2017 sampai dengan Desember 2017 penyesuaian gaji untuk pekerja bergaji perjam dan pekerja bergaji bulanan didasarkan kepada perubahan laju inflasi indeksi harga konsumen untuk DKI Jakarta bulan Januari 2016 sampai dengan Desember 2016 dengan kenaikan 
upah minimum 9\% (Sembilan persen) dan maksimum 20\% (Dua puluh persen), yang berarti bahwa pihak pengusaha telah sepakat dengan serikat pekerja untuk membuat suatu perjanjian kerja bersama yang isi terendahnya berdasarkan Peraturan Pemerintah No. 78 Tahun 2015 tentang Pengupahan, dan mendapatkan kenaikan upah maksimum yaitu 20\% kenaikan upah minimum.Pembayaran upah selama penugasan sementara dalam perjanjian kerja bersama menyatakan bahwa dalam hal seorang pekerja bergaji perjam untuk smentara harus menggantikan pekerjaan seseorang dari kelas jabatan yang lebih tinggi untuk jangka waktu sekurang-kurangnya 4 (empat) jam secara terus menerus tanpa terputus, pembayaran upahnya disesuaikan dengan upah dari jabatan yang lebih tinggi tersebut, apabila kurang dari 4 (empat) jam pembayaran tetap seperti pembayaran untuk kelas jabatannya sendiri. Hal tersebut tidak bertentangan dengan peraturan perundang-undangan, karena merupakan kesepakatan para pihak yang membuatnya antara pihak pengusaha dan pihak pekerja, asalkan sesuai dengan ketentuan Pasal 1320 KUHPerdata. Sehubungan dengan pembayaran upah selama penugasan sementara merupakan suatu kebijakan internal manajemen perusahaan, kebijakan pembayaran selama penugasan sementara bukan merupakan kebijakan yang bersifat umum.

\section{III.PENUTUP}

\section{A. Kesimpulan}

Berdasarkan paparan analisis di atas, maka dapat disimpulkan sebagai berikut:

1. Ketentuan pengupahan setelah berlakunya Peraturan Pemerintah No. 78 Tahun 2015 tentang Pengupahan yang menetapkan bahwa penentuan upah berdasarkan rumus: $\mathrm{UMn}=\mathrm{UMt}+\{\mathrm{UMt} \times($ Inflasit $+\% \Delta \mathrm{PDBt})\}$, sehingga tidak ada lagi peranan serikat pekerja untuk berunding dengan pengusaha terhadap penentuan upah di Jawa Barat. Hasil penelitian penulis terhadap ketiga Perjanjian Kerja Bersama pada perusahaan yang ada di Jawa Barat, PT Tokai Dharma Indonesia, PT Triple Ace Corporation, dan PT Enegizer Indonesia menggambarkan bahwa peran Serikat Pekerja yang berdasarkan peraturan perundang-undangan diatur bahwa dapat melakukan perundingan dengan pengusaha dalam penetapan 
upah yang diatur dalam Perjanjian Kerja Bersama, menjadi tidak ada karena penetapan upah ditentukan berdasarkan aturan struktur skala upah yang diatur dalam Peraturan Pemerintah Nomor 78 Tahun 2015 tentang Pengupahan. Peraturan Pemerintah Nomor 78 Tahun 2015 tentang Pengupahan, mengatur bahwa penetapan upah pada perusahaan harus ditetapkan berdasarkan struktur skala upah yang besarannya diatur dan dihitung oleh perusahaan tanpa memerlukan perundingan atau kesepakatan dengan serikat pekerja dalam Perjanjian Kerja Bersama. Lahirnya Peraturan Pemerintah Nomor 78 Tahun 2015 juga mengurangi peran Serikat Pekerja dalam kedudukannya pada Dewan Pengupahan yang semula tugasnya menurut undang-undang ketenagakerjaan adalah menetapkan upah minimum baik di pusat, daerah tingkat I maupun daerah tingkat II, sebab besaran upah minimum dihasilkan dari kenaikan inflasi dan pendapatan bruto nasional (bruto national income).

2. Peran Serikat Pekerja dalam penyusunan Perjanjian Kerja Bersama di Perusahaan adalah bahwa serikat pekerja diberikan kebebasan untuk merundingkan secara bipartit bersama pengusaha mengenai isi PKB yang mengikat kedua belah pihak. PKB yang dibuat antara PT Tokai Dhama Indonesia dengan Pimpinan Unit Kerja Serikat Pekerja Kimia, Energi dan Pertambangan (PUK SPKEP SPSI) menyatakan bahwa terdapat peranan serikat pekerja dalam mensejahterakan pekerja diantaranya mengenai tunjangan-tunjangan yang diberikan oleh pekerja berdasarkan golongan pekerjaan yang dilakukannya. PT. Energizer Indonesia dengan SP. KEP Unit Kerja PT. Energizer Indonesia terdapat peranan serikat pekerja dalam mensejahterakan pekerja diantaranya mengenai kenaikan upah untuk periode 11 April 2016 sampai dengan tanggal 10 Desember 2017, sedangkan untuk periode Januari 2017 sampai dengan Desember 2017 penyesuaian gaji didasarkan kepada Peraturan Pemerintah No. 78 Tahun 2015 tentang Pengupahan dengan kenaikan upah minimum sebesar 9\% (Sembilan persen) dan maksimum 20\% (dua puluh persen). 
Disamping terdapatnya peranan serikat pekerja terhadap isi PKB yang dibuat antara serikat pekerja dengan pengusaha, ternyata terdapat beberapa isi PKB yang tidak memerlukan peranan serikat pekerja karena isi PKB tersebut telah sesuai dengan ketentuan perundang-undangan yang berlaku.

\section{B. Saran}

Saran yang dapat Penulis berikan adalah seharusnya Pemerintah lebih cepat melakukan revisi ketentuan Undang-Undang No. 13 Tahun 2003 tentang Ketenagakerjaan terutama bagian pengupahan, supaya terciptanya kepastian hukum. Dengan lahirnya Peraturan Pemerintah No. 78 Tahun 2015 tentang Pengupahan terjadinya kesejangan antara peraturan yang dibawah dengan peraturan yang lebih tinggi yaitu terhadap UndangUndang No. 13 Tahun 2003 tentang Ketenagakerjaan. Dengan memperbaiki pengaturan tentang upah maka pekerja dapat hadir dalam proses produksi secara sehat jasmani dan rohani sehingga produktifitas kerjapun akan maksimal.

\section{IV.DAFTAR PUSTAKA}

\section{A. Buku}

Damanik, Sehat. Hukum Acara Perburuhan. Cetakan ke-4. (Jakarta: DSS Publishing, 2004.)

Yurikosari, Andari. Fungsi Serikat Pekerja Dalam Pasca Peraturan Pemerintah Nomor 78 Tahun 2015 tentang Pengupahan dalam pengupahan upah minimum.

\section{B. Perjanjian Kerja Bersama}

Perjanjian Kerja Bersama antar PT. Tokai Dhama Indonesia dengan Pimpinan Unit Kerja Serikat Pekerja Kimia, Energi dan Pertambangan (PUK SPKEP SPSI). Periode 2017-2019

Perjanjian Kerja Bersama antar PT. Energizer Indonesia dengan SP. KEP Unit Kerja PT. Energizer Indonesia. Periode 2016-2018

\section{Peraturan Perundangan}

Indonesia. Undang-Undang Dasar Negara Republik Indonesia Tahun 1945. . Kitab Undang-Undang Hukum Perdata. 
. Undang-Undang Nomor 13 Tahun 2003 tentang Ketenagakerjaan. . Undang-Undang Nomor 2 Tahun 2004 tentang Penyelesaian

Perselisihan Hubungan Industrial. . Peraturan Pemerintah No. 78 Tahun 2015 tentang Pengupahan.

\section{Internet}

Anonim. "Pengertian Serikat Pekerja Tujuan Tata Cara Pembentukan Buruh Fungsi Hak dan Kewajiban dan Perlindungan". http://www.landasanteori.com/2015/10/pengertian-serikat-pekerja-tujuantata.html. Diakses Tanggal 14 Mei 2018.

Ady Thea "Inilah Hasil Kajian LIPI Tentang Penyusunan Peraturan Pemerintah tentang Pengupahan". http://www.hukumonline.com/berita/baca/1t563895144a568/inilah-hasil-kajianlipi-tentang-penyusunan-pp-pengupahan. Diakses tanggal 20 Mei 2018.

Edmiraldo Siregar. "Upah Minimum Jakarta Tertinggi di Asia?" https://www.liputan6.com/news/read/3140684/upah-minimum-jakarta-tertinggidi-asia. Diakses tanggal 29 Mei 2018.

Fadhly Fauzi Rachman. "UMP Naik 8.71\%, Berapa Upah Minimum DKI 2018?" https://finance.detik.com/berita-ekonomi-bisnis/d-3705868/ump-naik-871-berapaupah-minimum-dki-2018. Diakses tanggal 18 Mei 2018

\section{E. Wawancara}

Mustiyah. Wawancara dengan penulis, Ketua Bidang Perempuan dan Sosek, Sekretariat Pimpinan Pusat Federasi Serikat Pekerja Kimia Energi dan Pertambangan Serikat Pekerja Seluruh Indonesia (PP FSP KEP SPSI), Jakarta 5 Juni 2018.

Mohammad Fandrian Hadisianto, Advokat/Wakil Direktur, Sekretarian Pimpinan Pusat Federasi Serikat Pekerja Kimia Energi dan Pertambangan (PP FSP KEP SPSI), Jakarta 5 Juni 2018.

Faisal Rizza, KASI Penanganan Mogok Kerja dan Penutupan Perusahaan, Kementrian Ketenagakerjaan Lantai 7, Jakarta 6 Juni 2018. 